\title{
Evaluation and Segmentation of Printing Accessories Suppliers Based on the Integration of the Best Worst Method and Fuzzy TOPSIS (Case Study at PT. Udaka Indonesia)
}

\author{
Wakhid Nur Hidayat ${ }^{1}$, Elly Wuryaningtyas Yunitasari ${ }^{1}$, Patrisius Edi Prasetyo ${ }^{1}$ \\ ${ }^{1}$ Faculty of Engineering, Departement of Industrial Engineering \\ Universitas Sarjanawiyata Tamansiswa, Yogyakarta, 55165 \\ email :wakhidnur567@gmail.com \\ doi: https://doi.org/10.31315/opsi.v14i2.5312
}

Received: $28^{\text {th }}$ July 2021; Revised: $4^{\text {th }}$ December 2021; Accepted: $6^{\text {th }}$ December 2021; Available online: 21 ${ }^{\text {st }}$ December 2021; Published regularly: December 2021

\begin{abstract}
In an increasingly competitive industrial environment, every company strives to increase the quality and efficiency of its product development process. PT. Udaka Indonesia, a clothing manufacturer, is experiencing raw material shortages that disrupt the company's production process. The goal of this research is to assess and segment the company's suppliers. The Best Worst Method (BWM) is employed for weighting criteria, and Fuzzy TOPSIS is used to rank alternative providers and segment them. The dimensions of capabilities (8 criteria with 26 subcriteria) and willingness (4 criteria with 15 sub-criteria) make up the company's supplier evaluation criteria. The evaluation results suggest that suppliers $A_{2}, B_{2}, C_{2}$, and $D_{2}$ are the best in terms of capabilities for label accessories, stickers, paper tags, and polybags, respectively, while $A_{1}, B_{2}, C_{2}$, and $D_{2}$ are the best in terms of willingness. Supplier segmentation results show that segmentation 1 includes suppliers $C_{1}, B_{1}, B_{3}$, and $D_{1}$, segmentation 2 includes supplier $A_{3}$, and segmentation 4 includes suppliers $A_{1}, A_{2}, B_{2}, B_{4}, C_{2}$, and $D_{2}$.
\end{abstract}

Keywords: Supplier evaluation; Supplier segmentation; Best Worst Method (BWM); Fuzzy TOPSIS

\section{INTRODUCTION}

In an increasingly competitive industrial environment, every company strives to increase the quality and efficiency of its product development process. The company does this to remain competitive with its rivals. One of the essential factors in improving product production performance is the availability of raw resources. According to Hendratmiko (2010), raw materials are the company's most crucial aspect in ensuring a smooth production process. The supplier is one factor that has a significant impact on the company's raw material availability.

PT. Udaka Indonesia is a clothing manufacturing firm. Fulfillment of the company's raw material needs, especially in printing accessories, is often rejected. In the last four months, $31.9 \%$ of arrivals experienced rejection due to raw materials coming from suppliers that were defective or not in accordance with company standards. In addition, the company's issues are tied to delivering raw materials from suppliers who frequently have mistaken quality and quantity and late deliveries, resulting in losses.

This study aims to determine the best supplier and the actions that need to be taken against each supplier through supplier evaluation and segmentation. Evaluation and segmentation of suppliers is one strategy to address these issues. Supplier segmentation is meant to classify suppliers based on their ability to supply raw materials to the company, and supplier evaluation is used as a reference in establishing the company's primary suppliers. Furthermore, the segmentation is used as a proposal for determining the company's activities towards its suppliers. Companies can consider suppliers to be maintained, upgraded, or replaced.

The Multi-Criteria Decision Making (MCDM) approach has been used to research supplier selection and assessment issues. Some research that raises related topics are as follows: 
Table 1. State of the art

\begin{tabular}{|c|c|c|}
\hline Name & Method & Criteria \\
\hline $\begin{array}{l}\text { Gupta and Barua } \\
\text { (2017) }\end{array}$ & $\begin{array}{l}\text { BWM and Fuzzy } \\
\text { TOPSIS }\end{array}$ & $\begin{array}{l}\text { Collaboration, environmental investment, and economic } \\
\text { benefits, availability of green competencies, } \\
\text { environmental management initiatives, research and } \\
\text { design initiatives, green purchasing, regulatory } \\
\text { obligations, and identification of market pressures and } \\
\text { demands are among the seven main criteria with } 42 \text { sub- } \\
\text { criteria (collaboration, environmental investment and } \\
\text { economic benefits, availability of green competencies, } \\
\text { environmental management initiatives, research and } \\
\text { design initiatives, green purchasing, regulatory } \\
\text { obligations, and market pressures and demands } \\
\text { identification). }\end{array}$ \\
\hline Adhiana et al. ( & Fuzzy Promet & $\begin{array}{l}\text { There are five requirements (competitive price, } \\
\text { availability of goods, quality of goods, delivery time, and } \\
\text { delivery capacity) }\end{array}$ \\
\hline $\begin{array}{l}\text { Dachyar and Maharani } \\
\text { (2019) }\end{array}$ & $\mathrm{BWM}$ and TO & $\begin{array}{l}\text { There are two dimensions, twelve primary criteria, and } 37 \\
\text { sub-criteria (ability: technical, product quality, delivery, } \\
\text { intangible, financial, sustainable, and organizational, as } \\
\text { well as willingness to improve performance, share } \\
\text { information, interdependence, and long-term } \\
\text { relationships) }\end{array}$ \\
\hline Lestari and Fauzi (2019) & AHP & $\begin{array}{l}\text { There are six main criteria and fifteen sub-categories } \\
\text { (quality, delivery, price, production capability, service, } \\
\text { vendor characteristics) }\end{array}$ \\
\hline $\begin{array}{l}\text { Sulistyoningarum et al } \\
(2019)\end{array}$ & $\begin{array}{l}\text { BWM,TOPSIS } \\
\text { and MOLP }\end{array}$ & $\begin{array}{l}\text { There are four main criteria and ten sub-categories (price, } \\
\text { delivery, capability, and flexibility) }\end{array}$ \\
\hline $\begin{array}{l}\text { Kurniawan and } \\
\text { Puspitasari (2021) }\end{array}$ & Fuzzy BWM & $\begin{array}{l}\text { There are five requirements (service, flexibility \& } \\
\text { delivery, reputation, quality, and purchase cost) }\end{array}$ \\
\hline Hidayat & $\begin{array}{l}\text { BWM and Fuzzy } \\
\text { TOPSIS }\end{array}$ & $\begin{array}{l}\text { There are two dimensions, } 12 \text { criteria, and } 41 \text { sub- } \\
\text { criteria. }\end{array}$ \\
\hline
\end{tabular}

The difference between this study and previous studies is that the Best Worst Method (BWM) is integrated with the Fuzzy TOPSIS method to produce supplier evaluation and segmentation. Determination of criteria and subcriteria considers two dimensions, namely the dimensions of capabilities and willingness, which can be seen in Table 2 and Table 3 . These two dimensions are used to consider the supplier's ability and willingness to supply raw materials to the company. In addition, previous studies only produced supplier evaluations in the form of the results of weighting criteria and rankings from their evaluations, while in this study, the evaluations obtained were used as the basis for segmenting suppliers to produce proposed company actions against their suppliers. The company's proposed actions are clarified by prioritizing suppliers based on the segmentation position and the circumstances of the related suppliers.

\section{METHOD}

This study was carried out at PT. Udaka Indonesia, which is located in Kalasan, Sleman, Yogyakarta. The investigation was carried out in the following manner:

\subsection{Determination of criteria and sub-criteria}

Identifying the criteria and sub-criteria desired by the firm is the first step in problemsolving. The findings of conversations between the company's Decision Maker (DM), typically the general manager and factory manager, and PPIC purchasing are used to determine these criteria. The two parties were picked because they have the most influence over its continuity and are the most knowledgeable about its suppliers. According to Rezaei et al. (2015), the evaluation criteria are divided into two categories: the capabilities dimension, which consists of eight criteria (ability: technical, product quality, delivery, service, financial, organizational, sustainable, and intangible) and 
the willingness dimension, which consists of four criteria (willingness: to improve performance). 24 sub-criteria in the capabilities dimension and 15 sub-criteria in the willingness

Table 2. Dimension Capabilities

\begin{tabular}{|c|c|c|}
\hline No. & Criteria & Sub Criteria \\
\hline & $\begin{array}{l}\text { Technical } \\
\text { Ability (C1) }\end{array}$ & $\begin{array}{l}\text { Production capacity and } \\
\text { facilities }\left(C_{11}\right)\end{array}$ \\
\hline & & Process capability $\left(\mathrm{C}_{12}\right)$ \\
\hline & & $\begin{array}{l}\text { Technological development } \\
\left(\mathrm{C}_{13}\right)\end{array}$ \\
\hline \multirow{2}{*}{2} & Product Quality & Product quality $\left(\mathrm{C}_{21}\right)$ \\
\hline & Capability (C2) & Product reliability $\left(\mathrm{C}_{22}\right)$ \\
\hline \multirow[t]{4}{*}{3} & Delivery Ability & Delivery constraints $\left(\mathrm{C}_{31}\right)$ \\
\hline & & On-time delivery $\left(\mathrm{C}_{32}\right)$ \\
\hline & & $\begin{array}{l}\text { Delivery quantity accuracy } \\
\left(\mathrm{C}_{33}\right)\end{array}$ \\
\hline & & Packing capability $\left(\mathrm{C}_{34}\right)$ \\
\hline \multirow[t]{2}{*}{4.} & Service Ability & Booking service $\left(\mathrm{C}_{41}\right)$ \\
\hline & & Repair service $\left(\mathrm{C}_{42}\right)$ \\
\hline \multirow[t]{4}{*}{5.} & Financial Ability & Competitive price $\left(\mathrm{C}_{51}\right)$ \\
\hline & & Discounts $\left(\mathrm{C}_{52}\right)$ \\
\hline & & Cost control $\left(\mathrm{C}_{53}\right)$ \\
\hline & & Shipping costs $\left(\mathrm{C}_{54}\right)$ \\
\hline \multirow[t]{4}{*}{6.} & $\begin{array}{l}\text { Organizational } \\
\text { Ability (C6) }\end{array}$ & $\begin{array}{l}\text { Organizational Management } \\
\left(\mathrm{C}_{61}\right)\end{array}$ \\
\hline & & $\begin{array}{l}\text { Communication } \\
\text { system/easiness }\left(\mathrm{C}_{62}\right)\end{array}$ \\
\hline & & Guarantees and claims $\left(\mathrm{C}_{63}\right)$ \\
\hline & & Document $\left(\mathrm{C}_{64}\right)$ \\
\hline \multirow[t]{4}{*}{7.} & Sustainability & Waste management $\left(\mathrm{C}_{71}\right)$ \\
\hline & & Recycling program $\left(\mathrm{C}_{72}\right)$ \\
\hline & & $\begin{array}{l}\text { Environmental certification } \\
\left(\mathrm{C}_{73}\right)\end{array}$ \\
\hline & & $\begin{array}{l}\text { Environmental health \& } \\
\text { safety }\left(\mathrm{C}_{74}\right)\end{array}$ \\
\hline \multirow[t]{3}{*}{8.} & $\begin{array}{l}\text { Intangible Ability } \\
\text { (C8) }\end{array}$ & $\begin{array}{l}\text { Reputation and position } \\
\left(\mathrm{C}_{81}\right)\end{array}$ \\
\hline & & Performance history $\left(\mathrm{C}_{82}\right)$ \\
\hline & & $\begin{array}{l}\text { Geographical } \\
\text { location/proximity }\left(\mathrm{C}_{83}\right)\end{array}$ \\
\hline
\end{tabular}

dimension were derived based on the findings of the Decision Maker (DM) discussion with the company's PPIC purchasing, as shown in Tables 2 and 3 below:

Table 3. Dimensions of Willingness

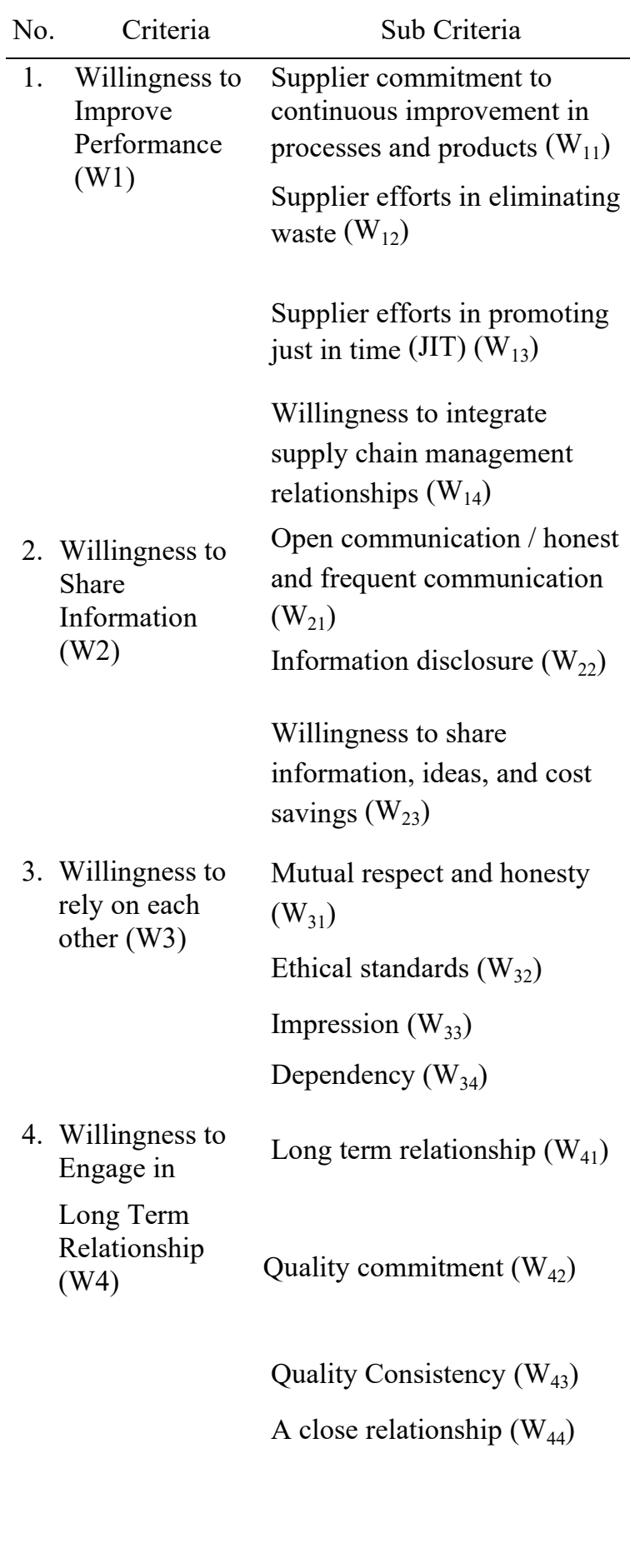




\subsection{Criteria Weighting}

The weighting of the previously derived criterion and sub-criteria is then applied. The company's policymaker, typically the Decision Maker, performs this weighing via a criterionweighted questionnaire (DM). The Best Worst Method is then used to process the weighted

1) Determine criteria

2) Determining the best and worst criteria

3) Determine preference criteria from Best-toOthers (BO) and Others-to -Worst (OW)

4) Determining the optimal weight $W_{B}$ $\min \xi$

s.t.

$\left|\frac{W_{j}}{W_{w}}-\alpha_{j w}\right| \leq \varepsilon$ for all $j$

$\left|\frac{W_{B}}{W_{j}}-\alpha_{B j}\right| \leq \epsilon$ for all $j$

$\sum_{\mathrm{j}} \mathrm{W}_{\mathrm{j}}=1$

$W_{j} \geq 0$ for all $j$.

5) Determining Consistency Ratio (CR)

$$
\mathrm{CR}=\frac{\varepsilon *}{\text { Consistency index }(\mathrm{CI})}
$$

Tabel 4. Consistency Index (CI) (Rezaei, 2015)

\begin{tabular}{cccccccccc}
\hline $\mathbf{a}_{\mathrm{Bw}}$ & $\mathbf{1}$ & $\mathbf{2}$ & $\mathbf{3}$ & $\mathbf{4}$ & $\mathbf{5}$ & $\mathbf{6}$ & $\mathbf{7}$ & $\mathbf{8}$ & $\mathbf{9}$ \\
\hline $\mathbf{C I}$ & 0.00 & 0.44 & 1.00 & 1.63 & 2.30 & 3.00 & 3.73 & 4.47 & 5.23
\end{tabular}

\subsection{Supplier Evaluation}

The weighted results and the results of the supplier assessment questionnaire done by PPIC purchasing are then used as input in the supplier evaluation. The Fuzzy TOPSIS approach is used for supplier evaluation. The steps are as follows, according to Chen (2015): Fuzzy TOPSIS:

1) Determining the weight of the criteria and the ranking of the criteria with variable linguistic

2) Calculating the normalized fuzzy decision matrix

$$
\begin{aligned}
& \tilde{r}_{i j}=\left(\frac{a_{i j}}{c_{i j}^{+}}, \frac{b_{i j}}{c_{i j}^{+}}, \frac{c_{i j}}{c_{i j}^{+}}\right), j \in B ; \\
& \tilde{r}_{i j}=\left(\frac{a_{j}^{-}}{c_{i j}}, \frac{a_{j}^{-}}{b_{i j}}, \frac{a_{j}^{-}}{a_{i j}}\right), j \in C ;
\end{aligned}
$$

3) Calculating the weighted normalized fuzzy decision matrix

$$
\begin{array}{r}
\tilde{V}=\left[\tilde{v}_{i j}\right]_{m \times n}, \quad i=1,2, \ldots, m, \\
j=1,2, \ldots, n
\end{array}
$$

4) Determining FPIS and FNIS values

$$
\mathrm{A}^{+}=\left(\tilde{\mathrm{v}}_{1}^{+}, \tilde{\mathrm{v}}_{2}^{+}, \ldots, \tilde{\mathrm{v}}_{\mathrm{n}}^{+}\right) \text {, }
$$

findings (BWM). Rezaei (2015) proposed the best worst technique to solve the problem of Multi-Criteria Decision Making for the first time (MCDM). The processes for utilizing the BWM approach to calculate the weight of the criteria are as follows:

$$
\mathrm{A}^{-}=\left(\tilde{\mathrm{v}}_{1}^{-}, \tilde{\mathrm{v}}_{2}^{-}, \ldots, \tilde{\mathrm{v}}_{\mathrm{n}}^{-}\right),
$$

5) Calculating alternative distance from FPIS and FNIS

$$
\begin{aligned}
& d_{i}^{+}=\sum_{j=1}^{n} d\left(\tilde{v}_{i j}, \tilde{v}_{j}^{+}\right), \quad i=1,2, \ldots, m \\
& d_{i}^{-}=\sum_{j=1}^{n} d\left(\tilde{v}_{i j}, \tilde{v}_{j}^{-}\right), \quad i=1,2, \ldots, m
\end{aligned}
$$

6) Calculating Closeness Coefficient (CCi) and determining alternative rankings

$$
\mathrm{CCi}=\frac{\mathrm{d}_{\mathrm{i}}^{-}}{\mathrm{d}_{\mathrm{i}}^{+}+\mathrm{d}_{\mathrm{i}}^{-}}, \mathrm{i}=1,2, \ldots, \mathrm{m}
$$

\subsection{Supplier Segmentation}

The supplier evaluation's Closeness Coefficient (CCi) results are utilized as input in the company's supplier segmentation. The CCI value of the capacities and willingness dimensions is used to determine segmentation; CCI values below 0.5 are defined as low, while $\mathrm{CCi}$ values in the 0.5-1.0 range are labeled high (Dachyar \& Maharani, 2019). Segmentation is classified into four categories, according to Rezaei and Ortt (2013):

a) Type $1 /$ Segmentation 1 (SM 1), namely the dimensions of capabilities and dimensions of willingness, are both low.

b) Type 2/Segmentation 2 (SM 2) is when the capabilities dimensions are low but high in the willingness dimensions.

c) Type $3 /$ Segmentation 3 (SM 3 ) is when the dimensions of capabilities are high but low in the dimensions of willingness.

d) Type 4/Segmentation 4 (SM 4) when the dimensions of capabilities and dimensions of willingness are both high.

\section{RESULTS AND DISCUSSION}

\subsection{Weighting Results}

After obtaining the criteria and sub-criteria, use the Best Worst Method to calculate the weight of each criterion and sub-criteria (BWM). Ms. Excel Solver was used to carry out 
Table 5. Consistency ratio calculation results

\begin{tabular}{|c|c|c|c|c|c|}
\hline Criteria & DM & $\xi^{*}$ & $a_{B W}$ & CI & CR \\
\hline \multirow{2}{*}{$\begin{array}{c}\text { Capabili } \\
\text {-ties }\end{array}$} & DM 1 & 0,045 & 7 & 3,73 & 0,01 \\
\hline & DM 2 & 0,080 & 9 & 5,23 & 0,02 \\
\hline \multirow[t]{2}{*}{$\mathrm{C} 1$} & DM 1 & 0,114 & 5 & 0,44 & 0,00 \\
\hline & DM 2 & 0,062 & 5 & 2,30 & 0,03 \\
\hline \multirow[t]{2}{*}{$\mathrm{C} 2$} & DM 1 & 0,000 & 2 & 0,44 & 0,00 \\
\hline & DM 2 & 0,000 & 2 & 0,44 & 0,00 \\
\hline \multirow[t]{2}{*}{ C3 } & DM 1 & 0,000 & 2 & 0,44 & 0,00 \\
\hline & DM 2 & 0,071 & 6 & 3,00 & 0,02 \\
\hline \multirow[t]{2}{*}{$\mathrm{C} 4$} & DM 1 & 0,000 & 2 & 0,44 & 0,00 \\
\hline & DM 2 & 0,000 & 3 & 1,00 & 0,00 \\
\hline \multirow[t]{2}{*}{ C5 } & DM 1 & 0,000 & 3 & 1,00 & 0,00 \\
\hline & DM 2 & 0,095 & 6 & 3,00 & 0,03 \\
\hline \multirow[t]{2}{*}{$\mathrm{C} 6$} & DM 1 & 0,054 & 5 & 2,30 & 0,02 \\
\hline & DM 2 & 0,047 & 4 & 1,63 & 0,03 \\
\hline \multirow[t]{2}{*}{$\mathrm{C} 7$} & DM 1 & 0,000 & 2 & 0,44 & 0,00 \\
\hline & DM 2 & 0,079 & 7 & 3,73 & 0,02 \\
\hline \multirow[t]{2}{*}{ C8 } & DM 1 & 0,042 & 3 & 1,00 & 0,04 \\
\hline & DM 2 & 0,097 & 9 & 5,23 & 0,02 \\
\hline \multirow{2}{*}{$\begin{array}{l}\text { Willing- } \\
\text { ness }\end{array}$} & DM 1 & 0,000 & 2 & 0,44 & 0,00 \\
\hline & $\mathrm{DM} 2$ & 0,088 & 7 & 3,37 & 0,02 \\
\hline \multirow[t]{2}{*}{ W1 } & DM 1 & 0,032 & 3 & 1,00 & 0,03 \\
\hline & DM 2 & 0,088 & 7 & 3,37 & 0,02 \\
\hline \multirow[t]{2}{*}{ W2 } & DM 1 & 0,042 & 3 & 1,00 & 0,04 \\
\hline & DM 2 & 0,042 & 3 & 1,00 & 0,04 \\
\hline \multirow[t]{2}{*}{ W3 } & DM 1 & 0,027 & 3 & 1,00 & 0,03 \\
\hline & DM 2 & 0,121 & 9 & 5,23 & 0,02 \\
\hline \multirow[t]{2}{*}{ W4 } & DM 1 & 0,000 & 5 & 2,30 & 0,00 \\
\hline & DM 2 & 0,088 & 7 & 3,73 & 0,02 \\
\hline
\end{tabular}

the weighting using the BWM approach. Based on the calculations, a consistency ratio (CR) of 0.016 was found. This demonstrates that the company's Decision Maker's (DM) assessment is relatively consistent. Table 5 shows the results of the company's Decision Maker's (DM) consistency ratio (CR) test of weighting criteria:
The weights of each criterion and subcriteria can be decided after the overall assessment has been consistent. The following tables show the outcomes of these calculations: Table 6 and Table 7.

Table 6. Dimensional weight capabilities

\begin{tabular}{|c|c|c|c|c|}
\hline Criteria & Weight & $\begin{array}{c}\text { Sub } \\
\text { criteria }\end{array}$ & Weight & $\begin{array}{l}\text { Global } \\
\text { weight }\end{array}$ \\
\hline \multirow[t]{3}{*}{$\mathrm{C} 1$} & 0,140 & $\mathrm{C}_{11}$ & 0,378 & 0,053 \\
\hline & & $\mathrm{C}_{12}$ & 0,514 & 0,072 \\
\hline & & $\mathrm{C}_{13}$ & 0,108 & 0,015 \\
\hline \multirow[t]{2}{*}{$\mathrm{C} 2$} & 0,293 & $\mathrm{C}_{21}$ & 0,500 & 0,147 \\
\hline & & $\mathrm{C}_{22}$ & 0,500 & 0,147 \\
\hline \multirow[t]{4}{*}{$\mathrm{C} 3$} & 0,110 & $\mathrm{C}_{31}$ & 0,119 & 0,013 \\
\hline & & $\mathrm{C}_{32}$ & 0,417 & 0,046 \\
\hline & & $\mathrm{C}_{33}$ & 0,310 & 0,034 \\
\hline & & $\mathrm{C}_{34}$ & 0,155 & 0,017 \\
\hline \multirow[t]{2}{*}{$\mathrm{C} 4$} & 0,163 & $\mathrm{C}_{41}$ & 0,292 & 0,047 \\
\hline & & $\mathrm{C}_{42}$ & 0,708 & 0,115 \\
\hline \multirow[t]{4}{*}{$\mathrm{C} 5$} & 0,142 & $\mathrm{C}_{51}$ & 0,434 & 0,061 \\
\hline & & $\mathrm{C}_{52}$ & 0,116 & 0,016 \\
\hline & & $\mathrm{C}_{53}$ & 0,260 & 0,037 \\
\hline & & $\mathrm{C}_{54}$ & 0,189 & 0,027 \\
\hline \multirow[t]{4}{*}{ C6 } & 0,058 & $\mathrm{C}_{61}$ & 0,081 & 0,005 \\
\hline & & $\mathrm{C}_{62}$ & 0,315 & 0,018 \\
\hline & & $\mathrm{C}_{63}$ & 0,410 & 0,024 \\
\hline & & $\mathrm{C}_{64}$ & 0,193 & 0,011 \\
\hline \multirow[t]{4}{*}{ C7 } & 0,035 & $\mathrm{C}_{71}$ & 0,143 & 0,005 \\
\hline & & $\mathrm{C}_{72}$ & 0,115 & 0,004 \\
\hline & & $\mathrm{C}_{73}$ & 0,426 & 0,015 \\
\hline & & $\mathrm{C}_{74}$ & 0,316 & 0,011 \\
\hline \multirow[t]{3}{*}{$\mathrm{C} 8$} & 0,060 & $\mathrm{C}_{81}$ & 0,444 & 0,026 \\
\hline & & $\mathrm{C}_{82}$ & 0,444 & 0,026 \\
\hline & & $\mathrm{C}_{83}$ & 0,111 & 0,007 \\
\hline
\end{tabular}


Table 7. Willingness dimension weight

\begin{tabular}{ccccc}
\hline Criteria & Weight & $\begin{array}{c}\text { Sub } \\
\text { criteria }\end{array}$ & Weight & $\begin{array}{c}\text { Global } \\
\text { weight }\end{array}$ \\
\hline W1 & 0,170 & $\mathrm{~W}_{11}$ & 0,351 & 0,060 \\
& & $\mathrm{~W}_{12}$ & 0,092 & 0,016 \\
& & $\mathrm{~W}_{13}$ & 0,350 & 0,060 \\
W2 & 0,309 & $\mathrm{~W}_{14}$ & 0,207 & 0,035 \\
& & $\mathrm{~W}_{21}$ & 0,292 & 0,090 \\
& & $\mathrm{~W}_{22}$ & 0,167 & 0,051 \\
$\mathrm{~W} 3$ & 0,237 & $\mathrm{~W}_{23}$ & 0,542 & 0,167 \\
& & $\mathrm{~W}_{31}$ & 0,289 & 0,068 \\
& & $\mathrm{~W}_{32}$ & 0,454 & 0,107 \\
& & $\mathrm{~W}_{33}$ & 0,179 & 0,042 \\
W4 & 0,282 & $\mathrm{~W}_{34}$ & 0,078 & 0,019 \\
& & $\mathrm{~W}_{41}$ & 0,115 & 0,032 \\
& & $\mathrm{~W}_{42}$ & 0,458 & 0,129 \\
& & $\mathrm{~W}_{43}$ & 0,355 & 0,100 \\
& & $\mathrm{~W}_{44}$ & 0,071 & 0,020 \\
\hline
\end{tabular}

\subsection{Supplier Evaluation and Segmentation Results}

Table 8 shows the results of the evaluation and classification of providers once they have been calculated:

Table 8. Evaluation results and supplier segmentation

\begin{tabular}{cccccc}
\hline \multirow{4}{*}{ Accessories Supplier } & & \multicolumn{3}{c}{$\begin{array}{c}\text { Dimension } \\
\text { Capabilities }\end{array}$} & \multicolumn{2}{c}{$\begin{array}{c}\text { Dimension } \\
\text { Willingness }\end{array}$} \\
\cline { 3 - 7 } & & CCI & $\begin{array}{c}\text { Classifi- } \\
\text { cation }\end{array}$ & CCI & $\begin{array}{c}\text { Classifi- } \\
\text { cation }\end{array}$ \\
\hline Label & A1 & 0,896 & High & 1,000 & High \\
& A2 & 0,986 & High & 0,895 & High \\
& A3 & 0,104 & Low & 0,668 & High \\
Sticker & B1 & 0,451 & Low & 0,253 & Low \\
& B2 & 0,979 & High & 0,833 & High \\
& B3 & 0,264 & Low & 0,313 & Low \\
& B4 & 0,857 & High & 0,543 & High \\
& C1 & 0,148 & Low & 0,484 & Low \\
Paper tag & C2 & 0,852 & High & 0,516 & High \\
& D1 & 0,000 & Low & 0,000 & Low \\
& D2 & 1,000 & High & 1,000 & High \\
\hline
\end{tabular}

On the capabilities dimension, suppliers A2, A1, A3 B2, B4, B1, B3, C2, C1, and D2, D1 are the providers of choice for label accessories, stickers, paper tags, and polybags. Meanwhile, suppliers for accessories, labels, stickers, paper tags, and polybags are in the following order: $\mathrm{A} 1, \mathrm{~A} 2, \mathrm{~A} 3, \mathrm{~B} 2, \mathrm{~B} 4, \mathrm{~B} 3, \mathrm{~B} 1, \mathrm{C} 2, \mathrm{C} 1$, and $\mathrm{D} 2$, D1.

Figure 2 shows the detailed findings of supplier segmentation in the meantime:

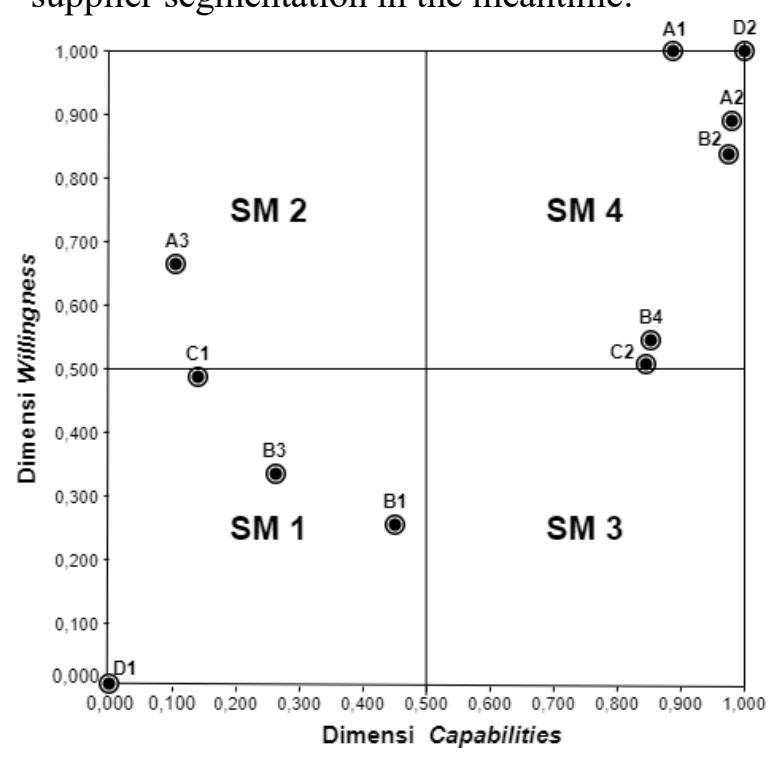

Figure 1. Supplier segmentation results

According to the results of the supplier segmentation, the eleven suppliers are separated into three segments: segmentation 1, segmentation 2, and segmentation 4:

a) Segmentation 1

In sector 1, suppliers of sticker accessories $\mathrm{B} 1$ and $\mathrm{B} 3$ are found. Other providers, such as B2 and B4, are, nonetheless, excellent (segment 4). This suggests that it is preferable to avoid using B1 and B3 suppliers to form ties with B2 and B4. Supplier D1 is a polybag provider who should be reconsidered. This is because this supplier performs poorly compared to its competitors, particularly supplier D2, which meets all of the company's requirements. Meanwhile, although in segment 1, paper tag accessories supplier C1 requires attention, this provider is critical as a backup to segment 4 supplier C2.

b) Segmentation 2

In segmentation 2, there is an A3 provider who is a label accessory supplier. Suppliers 
in this area should increase their ability to supply raw materials to the company in general. Companies can assist suppliers by enhancing their skills by recognizing and resolving difficulties they face. This can, however, be ruled out because the company should already have more connections with $\mathrm{A} 2$ and A1 label accessory vendors in segment 4.

c) Segmentation 4

Companies should make an effort to keep their ties with these vendors intact. Furthermore, suppliers in this category profit, implying that the relationship is more likely to develop into a partnership. Suppliers $\mathrm{A}_{1}$ and $\mathrm{A}_{2}$ (label accessories), $\mathrm{B}_{2}$ and $\mathrm{B}_{4}$ (sticker accessories), $\mathrm{C}_{2}$ (paper tag accessories), and $\mathrm{D}_{2}$ (paper tag accessories) make up this sector (polybag accessories).

\section{CONCLUSION}

According to the research findings, suppliers A2, B2, C2, and D2 are the best on the dimensions of capabilities for accessory labels, stickers, paper tags, and polybags. Suppliers A1, $\mathrm{B} 2, \mathrm{C} 2$, and $\mathrm{D} 2$ are the dimensions of willingness in the meantime. Suppliers C1, B1, B3, and D1 are the results of segmentation 1 based on the findings of the supplier segmentation, and the company is encouraged to look for a replacement/override from suppliers in this first segmentation. A3 providers are segmentation number two, and this is where organizations may work to strengthen their capabilities. While segmentation 4 includes suppliers A1, A2, B2, $\mathrm{B} 4, \mathrm{C} 2$, and $\mathrm{D} 2$, this segmentation firm is expected to maintain ties with more like partnerships.

It is recommended that more studies be done to identify the value classification of each factor in the supplier evaluation process. Its goal is to offer each of the assessments a precise classification.

\section{REFERENCES}

Adhiana, T. P., Krisnawati, M., \& Asyari, H. (2019). Evaluasi Kinerja Pemasok Bahan Baku Menggunakan Metode Fuzzy Promethee. Dinamika Rekayasa, 15(2), 107. https://doi.org/10.20884/1.dr.2019.15.2.27 1
Dachyar, M., \& Maharani, A. K. (2019). Supplier evaluation and segmentation in cheese companies using the best-worst method and TOPSIS. Proceedings of the International Conference on Industrial Engineering and Operations Management, July, 81-89.

Gupta, H., \& Barua, M. K. (2017). Supplier selection among SMEs based on their green innovation ability using BWM and fuzzy TOPSIS. Journal of Cleaner Production, 152, 242-258. https://doi.org/10.1016/j.jclepro.2017.03.1 25

Hendratmiko, Y. (2010). Analisis Pengendalian Persediaan Bahan Baku Pada Industri Kecil Menengah Mebel di Kota Kendal (Issue 1).

Kurniawan, V. R. B., \& Puspitasari, F. H. (2021). A Fuzzy BWM Method for Evaluating Supplier Selection Factors in an SME Paper Manufacturer. IOP Conference Series: Materials Science and Engineering, 1071(1), 012004. https://doi.org/10.1088/1757899x/1071/1/012004

Lestari, S., \& Fauzi, C. (2019). Evaluasi Supplier Kemasan Dus Dengan Menerapkan Metode Analytical Hierarchy Process (Ahp) (Studi Kasus Di Pt Innovation). Journal Industrial Servicess, 4(2). https://doi.org/10.36055/jiss.v4i2.5153

Mokhtarian, M. N. (2015). A note on "extension of fuzzy TOPSIS method based on interval-valued fuzzy sets." Applied Soft Computing Journal, 26, 513-514. https://doi.org/10.1016/j.asoc.2014.10.013

Rezaei, J. (2015). Best-worst multi-criteria decision-making method. Omega (United Kingdom), 53, 49-57. https://doi.org/10.1016/j.omega.2014.11.0 09

Rezaei, J., \& Ortt, R. (2013). Multi-criteria supplier segmentation using a fuzzy preference relation-based AHP. European Journal of Operational Research, 225(1), 75-84.

https://doi.org/10.1016/j.ejor.2012.09.037

Rezaei, J., Wang, J., \& Tavasszy, L. (2015). Linking supplier development to supplier segmentation using Best Worst Method. 
Expert Systems with Applications, 42(23), 9152-9164.

https://doi.org/10.1016/j.eswa.2015.07.07 3

Sulistyoningarum, R., Rosyidi, C. N., \& Rochman, T. (2019). Supplier selection of recycled plastic materials using best worst and TOPSIS method. Journal of Physics: Conference Series, 1367(1). https://doi.org/10.1088/1742$6596 / 1367 / 1 / 012041$ 